\title{
Diversity of Pteridophyta in Lubuak Mato Kuciang Padang Panjang, Sumatera Barat
}

\author{
Skunda Diliarosta*, Rehani Ramadhani, Dewi Indriani
}

kunda Diliarosta*, Rehani

Ramadhani, Dewi Indriani

Department of Natural Sciences, Faculty of Mathematics and Natural Science, Universitas Negeri Padang, INDONESIA.

\section{Correspondence}

\section{Skunda Diliarosta}

Department of Natural Sciences, Faculty of Mathematics and Natural Science

Universitas Negeri Padang, INDONESIA

Phone No: 57420106

Fax: 7058772

E-mail: skunda@fmipa.unp.ac.id

History

- Submission Date: 03-11-2019;

- Review completed: 06-12-2019;

- Accepted Date: 12-12-2019.

DOI : 10.5530/pj.2020.12.27

Article Available online

http://www.phcogj.com/v12/i1

Copyright

(C) 2020 Phcogj.Com. This is an openaccess article distributed under the terms of the Creative Commons Attribution 4.0 International license.

\section{ABSTRACT}

Padang Panjang city located at an altitude of 650 to 850 meters above sea level, so that weather cold and cool. Temperatures range from $17{ }^{\circ} \mathrm{C}$ to $26.1^{\circ} \mathrm{C}$ and with $3,295 \mathrm{~mm} /$ year of rainfall. This area is rich in the diversity of flora and fauna. Pteridophyta is one of the flora that has a unique diversity of species and has the potential for tremendous utilization such as ornamental plants, medicines and vegetable plants. The study was conducted in the Lubuak Mato Kuciang area of Padang Panjang City, West Sumatra, which is currently being developed for tourism. The aim of this study obtain collect data and information about the diversity of ferns in Lubuk Mato Kuciang. The activities of the study are conducted to collect species as much as possible. Identification of fern species was carried out in the Laboratory of Educational Science. Mathematics and Science Faculty. Padang State University. The identification of flora was analyzed descriptively. The identification species results were obtained through descriptive analysis. The results of this study obtains that there were 21 species of fern that include 11 families. They were namely; Selaginellaceace including Selaginella sp, Selaginella plana Hieron and Selaginella wildenowii; Lomariopsidaceae family including Neplholepisbiserrata; Pterisvittata L; Adiatumpedatum; Cyatheaceae family, including Cyatheacontaminans; Gleicheinaceae including Gleichenialinearis; Marrattiaceae family including Marrattiafraxinea; Lindsaeaceae family including Sphenomeris chinensis; and Dryopteridaceae family including Nephroletis cordifolia.

Key words: Identification, Lubuk mato kuciang, Diversity, Pteridophytha.

\section{INTRODUCTION}

Indonesia has 750 million hectares areas that consist of the land area is 193 million hectares (24.7\%). ${ }^{1}$ The land ecosystem is being placed on flora and fauna. Based on the diversity of species flora, Indonesia has more than 30,000 flora species. Among the thirty thousand species are still little cultivated, while approximately $74 \%$ still grew wild in the forests. ${ }^{2}$ Indonesia's tropical rainforest is known as the richest forest plant species and has the most complex ecosystems in the world. Furthermore, according to Groobridge (1992) cit Suryana (2009) biodiversity of Indonesia ecosystem is the second largest in the world. ${ }^{3}$ One type of the group of flora are ferns. ${ }^{3}$ This is a plant cormophyte spora can live easily in a wide range of habitats and anywhere either as epiphytic, terrestrial as well as in the water ecosystem. ${ }^{4}$ The abundance and distribution of ferns are very high, especially in the rainy season. Ferns are also abundant in the montane forest. ${ }^{4}$

Fern is a plant that is easy developing with spores cormophyte and live in various habitats. Abundance and spreading vary widely because the spores are easily carried by wind or other medium, and able to survive in less optimal conditions. ${ }^{5}$ Ferns Pteridophyta is included in the division that has kormus. It means that the body can be divided into three main parts, the roots, stems, and leaves. Pteridophyta fern which is one group of Indonesian flora with high diversity and wide distribution. ${ }^{6}$ As we know that ferns are found in the tropical and subtropical with different heights, with the habitat in soil, vines, and epiphytes. ${ }^{7}$ Which in this case Indonesia is an area that has a tropical climate and the many ferns that life as a wild plant that is ignored its existence by people. Growth development of the Pteridophyta ferns are influenced by abiotic and not abiotic factors. Abiotic factors are a humid place, shaded and also in the open area environment. ${ }^{8}$

Generally, ferns are found to have a function as raw material for pharmaceuticals, as vegetable consumption by the public and many of them ferns are also useful as ornamental plants, with a living habitat tropical areas. ${ }^{9}$ For example Helminthostachys zeylanica (Linn.) Hook. This plant is one of the ferns that have long been used by people as a traditional medicine. ${ }^{10}$ While, Cyathea ferns have a major role in the balance of forest ecosystems, because of their function as preventing erosion and regulating water use planning. Deployment and diversity of ferns are very large, as well as the potential and the benefits are quite important both for ornamental plants, vegetables, medicines and its role as the balance of the ecosystem.

\section{RESEARCH METHODS}

This research was conducted in the area of Lubuk Mato Kuciang, Padang Panjang, West Sumatra in April 2019. This study was conducted to determine the type of fern that exist in the Lubuak Mato Kuciang and a long field region. Sampling was 
done by tracking the research area has been divided into 6 areas of deployment. All species of ferns are found in the field and herbarium specimens were made from sample fresh. All collections of specimen ferns were given number and recorded at the time of the field. Data recorded among other characteristics of plants, leaf shape, stem and habitat. Before being made herbarium, the plant was photographed in advance, so that some photos will support the identification process to give result in many ferns species. Specimens fresh fern was obtained put in a plastic bag to be observed. While complete ferns specimen samples to be made herbarium are covered with papers

\section{RESULTS AND DISCUSSION}

Based on the results of data plant species that exist in the Lubuak Mato Kuciang region can be shown in Table 1 .

Results of fern plant Identification in the Lubuak Mato Kuciang area consist of;

\section{Selaginellaceae}

Habitat humid place, clinging to the rocks. Selaginella serves as a medicinal plant that is as a sedative and post-natal care, anti-cancer, antimutagenic, anti petoksida lipid, anti-cardiovascular, cancer of the nose, throat, drug fever, diarrhea and dysentery. Selaginella is a nail plant, leaves a small, single, branch saping arranged in four rows, namely two rows side consists of large leaves which are often easy to fall off, 2 front row of leafy small seat attached (On the trunk of the lower two kinds of leaves nearly or completely resemble one another there. Sporofil greater than sporangia, collected into a grain terminal, rectangular sometimes - sometimes slightly flattened (Figure 1).

\section{Nephrolepis biserrate}

Root of Nephrolepis branched. Light green. Being on the ground. If it hits the ground put out roots. Absorb or creeping rhizomes. Nephrolepis rod not jointed. Rod surface slippery. The trunk grows straight. Grow back. The trunk is hard. Nephrolepis has a high leaf density. The leaf blade is generally curved. Lancet shaped. Wedge-shaped base. Parallel leaf veins (Figure 2).

Table 1: Results of data plant species that exist in the Lubuak Mato Kuciang region.

\begin{tabular}{|c|c|c|}
\hline No. & Family & Type \\
\hline 1 & Selaginella sp & Selaginellaceae (1) \\
\hline 2 & Neplholepis biserrata & Lomariopsidaceae (2) \\
\hline 3 & Tectaria crenata Cav & Polypodiaceae (3) \\
\hline 4 & Pityrogramma calomelanos (L.) & Pteridaceae (4) \\
\hline 5 & Cyathea contaminans & Cyatheaceae (5) \\
\hline 6 & Hymenophyllum & Hymenophyllaceae (6) \\
\hline 7 & Hymenophyllum imbricatum & Hymenophyllaceae (7) \\
\hline 8 & SelaginellaplanaHieron & Selaginellaceae (8) \\
\hline 9 & Hymenophyllum trichomanes & Hymenophyllaceae (9) \\
\hline 10 & Pteris vittata $\mathrm{L}$ & Pteridaceae (10) \\
\hline 11 & Nephrolepis biserrata & Nephrolepis (11) \\
\hline 12 & Filiciinae & Leptosporangiate fern (12) \\
\hline 13 & Adiatum pedatum & Pteridaceae (13) \\
\hline 14 & Dicranopteris linearis & Gleicheniales (14) \\
\hline 15 & Hymenophyllum austrate & Hymenophyllum (15) \\
\hline 16 & Marrattia fraxinea & Marrattiaceae (16) \\
\hline 17 & Gleichenia linearis & Gleicheinaceae (17) \\
\hline 18 & Selaginella wildenowii & Selaginellaceae (18) \\
\hline 19 & Platycerium bifurcatum C.Chr & Polypodiaceae (19) \\
\hline 20 & Sphenomeris chinensis & Lindsaeaceae (20) \\
\hline 21 & Nephroletis cordifolia & Dryopteridaceae (21) \\
\hline
\end{tabular}

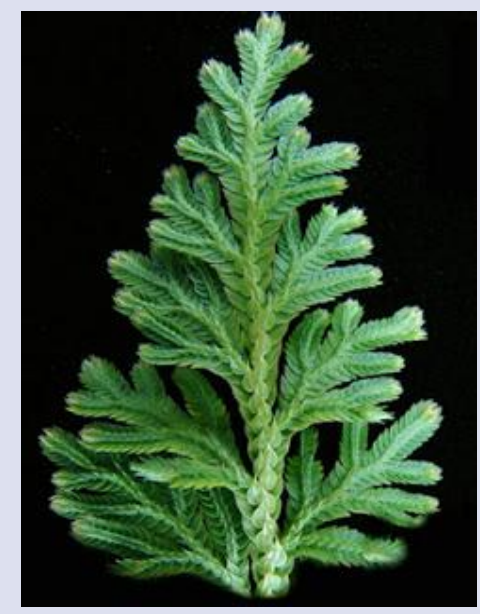

Figure 1: Selaginellaceae.

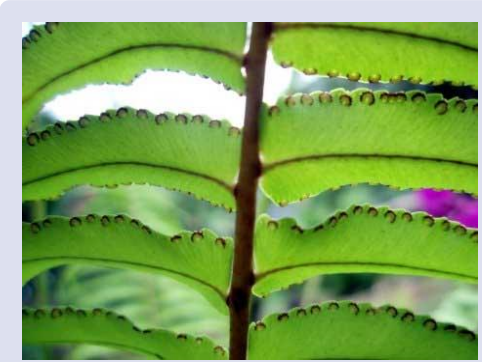

Figure 2: Neplholepis biserrata.

Nephrolepis is a group of ferns around easily recognized by frond elongated shape sword, easily found growing at the edges river or on the trunk palmas well as other trees. Rhizome thin, resembling fibers roots. From the rhizome grows shoots elongated, can reach $1.5 \mathrm{~m}$ in length, with children pinnate leaves composed of a single, similar sword or eyes spear, its benefits as an ornamental plant, as materials for de-worming.

\section{Tectaria crenata Cav}

This Fern has a slim and long rhizomes, rooted in the soil, the young leaves curl and will open when it is mature. The leaves are not ental. Leaf shape is getting to the end of the shrinking or can be pointed tip. The color green pinnate leaf veins, but the veins of the leaves are not branching. Leaf texture like a membrane with a fairly smooth surface. The leaves of this species including a single leaf. Rod shape is round, with a smooth surface not having joint. The size of the trunk about $33 \mathrm{~cm}$ long, brown. This species has a dichotomous root fiber. Sorus sporangia contain many located on the underside of leaves, sorus ball shape (Figure 3).

\section{Pityrogramma calomelanos (L.)}

This fern is more commonly known as silver ferns. In young plants throughout ental kind covered by silvery or white flour straw, Because the spores are like flour under the surface of the leaves. the people referred to the name of the silver fern. It has small leaves but has many fronds whose length ranges from $50-100 \mathrm{~m}$. The color of the frond shaft is black, scaly on the base and not shiny. Leaves on a single leaf dark green, serrated leaves, with an average leaf width $1-2 \mathrm{~cm}$ and the end of the tapering leaves, leaf bone being pinnate. Circular cylindrical rod-shaped with a size of about $3 \mathrm{~cm}$, dark brown medium brown rather than green light. has a fibrous root. These spores in plants located on the underside of the leaves and spread. Rhizome has a short, upright, rhizomes are brown scales. found in rocky areas and on hillsides and old wall and is often found on the bank of whether open or unprotected (Figure 4). 

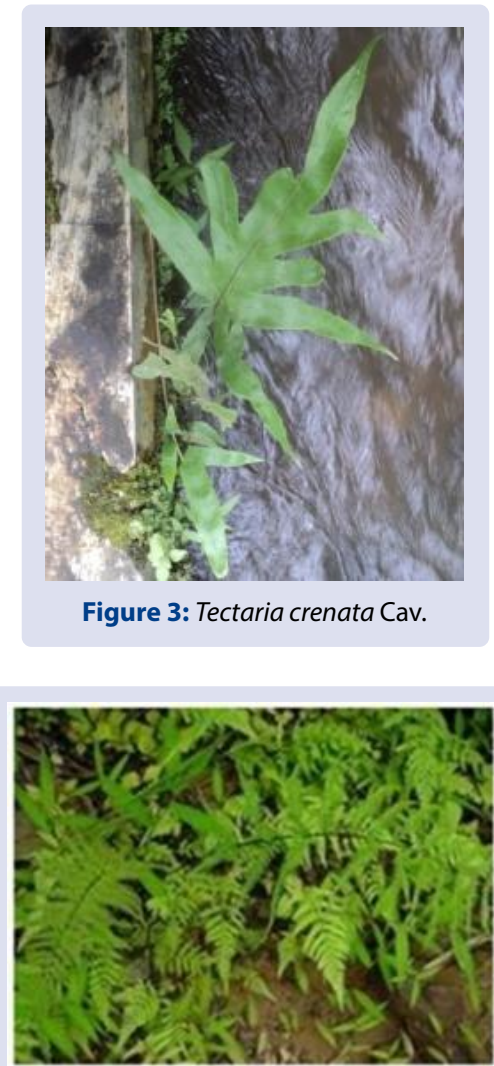

Figure 4: Pityrogramma calomelanos (L.).

\section{Cyathea contaminan}

Cyathea contaminan is a tree-shaped fern. the morphologic is like a palm tree so easily distinguished from other types of ferns. The natural growth is not alone but mixed with other species. Sometimes, they are in groups and are often found on the slopes land, and are open or sheltered places. These ferns leave roll and on the stalks are find fine hairs. The root are black and fibrous, coarse, dense and thick and slightly tapered cover kormus area at this plant. Stature slim, black trunks covered by the roots of coarse, dense and thick, black color. Spore sacs located between leaf child bone, in groups of rounded shape.

\section{Hymenophyllum}

This Hymenophyllum life as an epiphyte on a tree trunk. It has brown stipe. Branched pinnate. Having spores at the tip of the leaf. Characteristic of this fern has a lamina is transparent because it is composed of a single layer of cells. Lamina is a broad fan-shaped or oval and 15-35x15-24 mm measure.

\section{Hymenophyllum imbricatum}

The plant is herbaceous plant, roots are in the form of rhizomes, stems are brown. These spikes have the same types that other tribesmen, generally have a soft texture and thin, not unlike like a membrane. The rhizome is long slender but stiff like wire. Narrow blade leaves with a texture like a thin membrane, green. spore bag located under the child leaf. Serrated leaf edge irregular or notched at the top.

\section{Selaginella plana Hieron}

Rane ferns blue (Selaginella plana) is an herbaceous plant with a short characteristic, woody, has a direct ramification, has small leaves and arranged encircling the stem. The structure of the leaf is dense. The trunk is located at ground level and sometimes roots form new plants. Its roots spread on the surface of the rock and a rock crevice. The leaves reflect bluish color when in the shade. This plant can be used as ornamental plants, vegetables (young shoots).

\section{Hymenophyllum trichomanes}

Hymenophyllum trichomanes are a type of ferns that grow as epiphytes on tree trunks. The plant is herbaceous and has a d leaf green and thin like membranes. Lanceolate leaf shape and sporofil and tropofil indistinguishable. It features free branching spikes with layout leaf rosette. The fern rod is segmented. Hymenophyllum have a homospora be a sorus carrier located below the surface of the leaves.

\section{Pteris vittata $\mathrm{L}$.}

Pteris vittata is ferns that live in the ground, walls, and cliffs. These kinds are growing in high humidity. The rhizomes spread on the surface of rocks and roots come into the crevices of rocks. Pteris vittata is an herbaceous plant, has a pinnate compound leaves, its leaf edges flat. Leaf elongated shape, measuring $\pm 3.5 \mathrm{~cm}$. Pteris vittata has spherical rod longitudinally grooved, long jointed and rigid, smooth surface as like the vine. the stem does not have hair. Pteris vittata has color brownish-green stems. The roots of Pteris vittata are located at the base of the upright rhizomes and roots form thin, rough, and the color is dark brown. The lower surface of the leaves Pteris vittata is singular of sorus, and each sorus contains a group of sporangia (spore) (Figure 5).

\section{Nephrolepis biserrata}

Nephrolepis biserrata grows out in the open, sometimes grown in a sheltered place, in the lowlands that are not too dry. In addition to living in the land, but it also found in the palm trees as an epiphyte. It can also grow in between the rocks if filled with hummus. Soft leaf stalk scaly, the scales are brown. Lush leaf shape larger than another of the plant leaves, in the fertile ground, is the leaves form like taper with earing. The spores are located just off the leaves. They are easily distinguished by the type of another fern because the location of the spores is uneven. These plants include shrubs. The stem is slender and elongated rounded green. Roots in the form of fibers and black (Figure 6).

\section{Filiciinae}

Filiciinae has leaf large size, leaves are sitting on the stems to form wings, arranged in the form sorus sporangia in sorus leave. location of the leaf is on a surface (top, bottom), at the tip / at the edge.

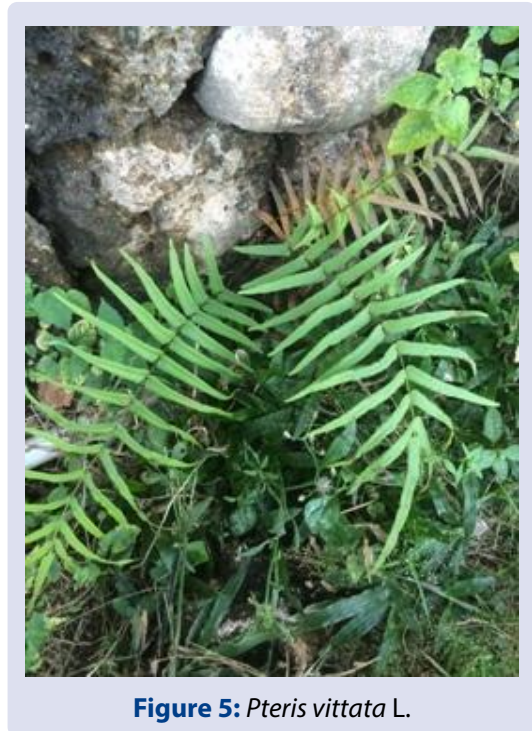




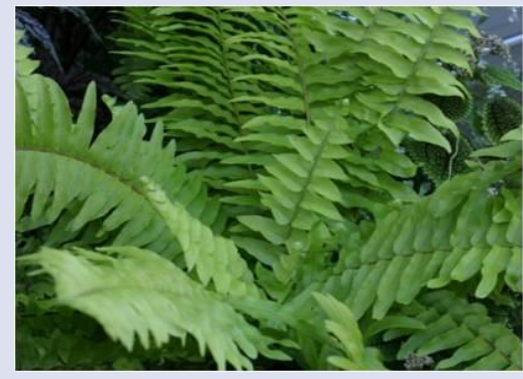

Figure 6: Nephrolepis biserrata.

\section{Adiantum pedatum}

Adiantum plants are plants that reproduce by spores. Adiantum plants included in the class of ferns (Pteridophyta). This plant includes a group of Pterudophyta because it can be distinguished between the stems, leaves, and roots. In general, this plant life on the land in a way and have clustered root fibers are protected calyptra root tip. Most of the plants live in places that are protected. The root of this plant is a rhizome erect. The roots of the plant are more ascending or climbing. Rhizome roots are a form of short segmented roots that appear in the form of fibers. At the root, a tip is protected by roots hoods. Shiny black Adiantum plant has stems erect or semi-erect barbed and has the scales are soft or hard.

\section{Dicranopteris linearis}

Dicranopteris linearis grow as the bush, are surface land however there are also grown attached to the surface of the rocks. The plant has the spherical rod, slithers below ground level, brushy, green color with a blackish-brown fur. The plant has finger structure leaves, the odd-pinnate leaves of the child, forming lines, the tips of the blunt ends of flat, smooth, green. Spores included in homospora, sporangium is arranged in a line, along the underside of the leaves are fertile. The spores are round, brown color. Root fibers, yellowishwhite (Figure 7).

\section{Hymenophyllum austrate}

These fern life as epiphytes, and really like in a damp place. The leaves are small and thin, often only consist of one layer of cells. But there are also larger with thick leaves can be 3-4 layers of cells. Fertile leaf shape together with sterile leaves. Sporangium collected in the sorus that is located on the edge of the leaf. Sorus has indusium shaped like a cup or lip. Sporangium short-stemmed or stemless, have annular lying transverse or oblique. Prothallium shaped trophy (Figure 8).

\section{Marrattia fraxinea}

Grow on land, green resembles talus liverworts. Some thorns consist of a metamorphosis stipule. The leaves are very large compound, pinnate double up a few times. Short stem erect. Has a soft petiole stipules. Sporangium on the underside of the leaves and have a thick wall, do not have a ring (annulus), opens with a gap or hole (Figure 9).

\section{Gleichenia linearis}

The fern is annual creeping, often form the strands 'sheet' meeting. Creeping rhizome root, sometimes climbing or hanging, leave far apart from one another, is not segmented, branched like fork or so many branches. Each branch except the top, there are two segments of the transverse and curved leaf. Heading elongated ribbon-shaped leaves, smooth, flat edges, blunt edges and slightly curled, each leaf is generally found sorus over (Figure 10).

\section{Selaginella wildenowii}

Rane nail smooth (Selaginella willdenowii) has leaf the proliferation of more pointed. The structure even more tightly. The trunk is located at ground level and sometimes rooted form new plants.

\section{Platycerium bifurcatum C.Chr}

Platycerium bifurcatum C.Chr (Deer Horn Paku) has roots that growth Platycerium tufted from a short rhizome imposed from base leaves and lush foliage. Platycerium an upright plant attached to the host. Platycerium rod to form of rhizomes. The leaves of type shields, dried

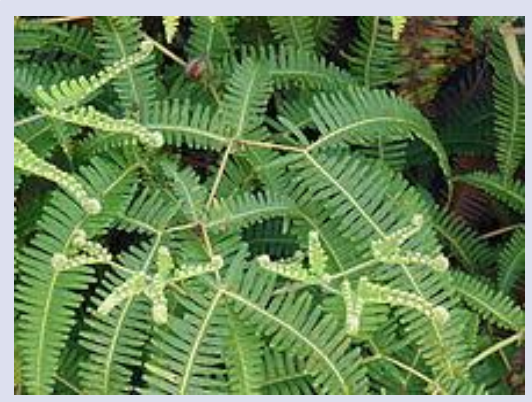

Figure 7: Dicranopteris linearis.

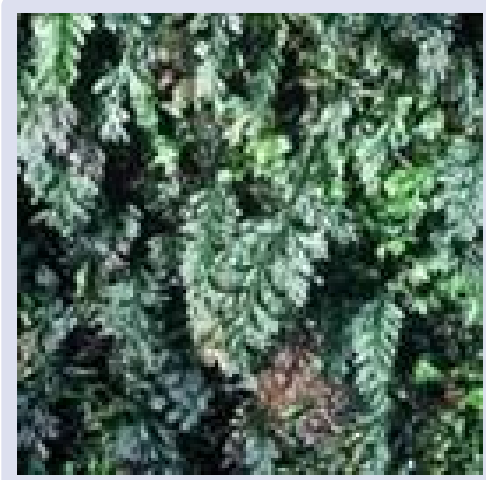

Figure 8: Hymenophyllum austrate.

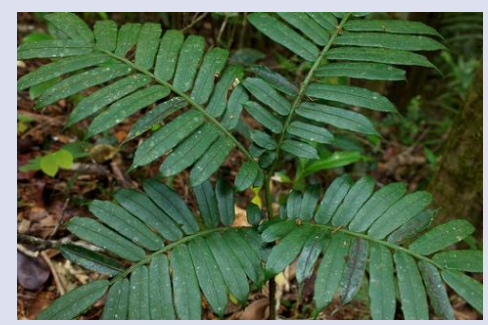

Figure 9: Marrattia fraxinea.

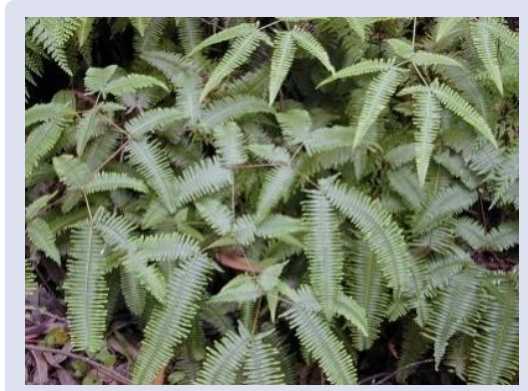

Figure 10: Gleichenia linearis. 
and lightly browned on the growing leaf leaves hanging down green colored to resemble deer antlers.

\section{Sphenomeris chinensis}

Sphenomeris has compound leaves with pinnate portions. Sphenomeris also has rhizome roots that grow near the soil surface. And the hard stems that grow upwards. The young frond always rolls up and becomes a hallmark.

\section{Nephroletis cordifolia}

Nephrolepis cordifolia grows on land. Based many observations Nephrolepis cordifolia grow in soil, mixed with grass. Epiphytes plant grows on open tempt, these plants are in a place exposed to direct sunlight or slightly shady and resistant to wind. Based on the observations, Neprolepais cordifolia has light green leaves. The leaves are elongated, tapered leaf tip, leaf base romping or flat. Roots pinnate, the upper surface of the sink and on the bottom surface arise pinnate. Texture thin leaves. On the leaf surface are formed as small yellow feathers smooth, so that its surface remains smooth. Leaf edge is smooth. leaves are sitting on the stem and alternate leaves has bright green, leaf edges flat, with surface leaves have small scales. Leaves surface have small scales that cover the upper surface of the leaves on the hydathodes. Stem has bluish brown, round-shaped grooved. Rod surface is covered with thin scales very dense yellow. Straight rod and round rod are branching, shape is not grooved. Nephrolepis roots are fibrous roots.

Diversity of the species is a characteristic level of biological communitybased organizations. Ferns in Mato Kuciang Lubuak region, Padang Panjang, West Sumatra, as seen in Table 1, it can be seen that in the region there are 21 kinds of nails included into 11 families. Adjustment of each individual depends on environmental factors, for example, topography, soil, moisture, temperature, and climate.

Region Lubuak Mato Kuciang, Padang Panjang is a city that is at high altitude which is between 650 to 850 meters above sea level, is located in a mountainous region cool air with air temperature maximum of $26.1^{\circ}$ $\mathrm{C}$ and cold air with a minimum temperature of $17^{\circ} \mathrm{C}$, with a fairly high rainfall with an average of $3,295 \mathrm{~mm} /$ year.

Wealth of fern found in the area affected by temperature and humidity. When the air temperature increases, transpiration, and evaporation also increased, in turn, will increase the moisture. Increasing air temperature also increases the relative humidity.

The diversity of types of fern can be known through the sorus layout arrangement. Each type of fern has a different layout sorus. Although the same location but other characteristics can be used as a differentiator in the determination of these spikes, such as the number of spores, spore form and whether there is indicium.

Environment as a learning resource is very important because a lot of material relating directly to the surrounding natural environment.
Enterprises using the environment to bring the student to the student lucrative field. Students will gain firsthand experience of what is being learned.

\section{CONCLUSIONS}

Based on research was conducted in Lubuak Mato Kuciang, Padang Panjang can be concluded that there are 21 species of spikes include in 11 families are founded. Species are from families Selaginellaceace including Selaginella sp, Selaginella plana Hieron, and Selaginella wildenowii. Lomariopsidaceae family consists of Neplholepis biserrata. Family Polypodiaceae include Tectaria crenata Cav, Filiciinae, and Platycerium bifurcatum C.Chr. Pteridaceae family consists of; Pityrogramma calomelanos (L.), Pteris vittata L, Adiantum pedatum. Cyatheaceae family including Cyathea contaminans. Hymenophllaceae family including Hymenophyllum, Hymenophyllum imbricatum, Hymenophyllum trichomanes, and Hymenophyllum austrate. Nephrolepis family including Nephrolepis biserrata. This Pteridophyta is feared to be lost when the location develops into a tourist area.

\section{SUGGESTION}

Based on the results of this research can be useful for the development of media in the form of an atlas that contains a collection of ferns. For the further research can start viewing changes in crop due to a long drought at present.

\section{REFERENCES}

1. Suraida, Susanti T, Amriyanto R. Plant diversity paku (Pteridophyta) in forest park get to know the city of Jambi. Proceedings Semirata State University of Lampung. 2013.

2. Romaidi, Maratus S, Minarno BE. The types of host plants Paku epiphytes dab SoeryolnTahuraRonggoCangar. El-hayah. 2012;3

3. Suryana. Paku Terrestrial Biodiversity of Plants and epiphytes in the area of geothermal power plants Kamojang Kab. Garut Jawabarat. Biotika Journal. 2009;1.

4. Widhiastuti R, TA Aththorick, WDP Sari. Structure and composition of plant fern forest area sinabung in Karo. Biological Journal of Sumatra. 2006;2.

5. Efendi, Henry W. Study of plant biodiversity inventory nails in Coban Rando Tourism Regions Malang. Cogito Ergo Sum Journal. 2013;2(3).

6. Kurniawati E, Wisanti Fida Rachmadiarti. Diversity in forest area pteridophyta waterfall girimanik wonogiri. Lentera Bio. 2016;5(1):74-8

7. Jamsuri. Diversity plant spikes around cikaracak curug, bogor, West Java Unpublished thesis. Syarif Hidayatullah State Islamic University; 2007.

8. Arini Dwi DI, Kinho Julian. Diversity of plants paku (Pteridophyta) on the threshold mountain nature reserve in North Sulawesi. Forestry Research Institute. Manado; 2012

9. Ridianingsih, Dwi Swastanti. Plant inventory paku (Pteridophyta) in post Ngagelan Rowobendo Alas Purwo National Park Banyuwangi. Bioeksperimen Journal. 2017;3(2)

10. Fitrya LA. Test of anticancer activity in vitro with the P-388 murine cells flavonoid compounds faction appoints ethyl acetate plant roots of heaven (Helmynthostachis Zeylanica (Linn) Hook). Science Research Journal. 2009;12. 


\section{GRAPHICAL ABSTRACT}

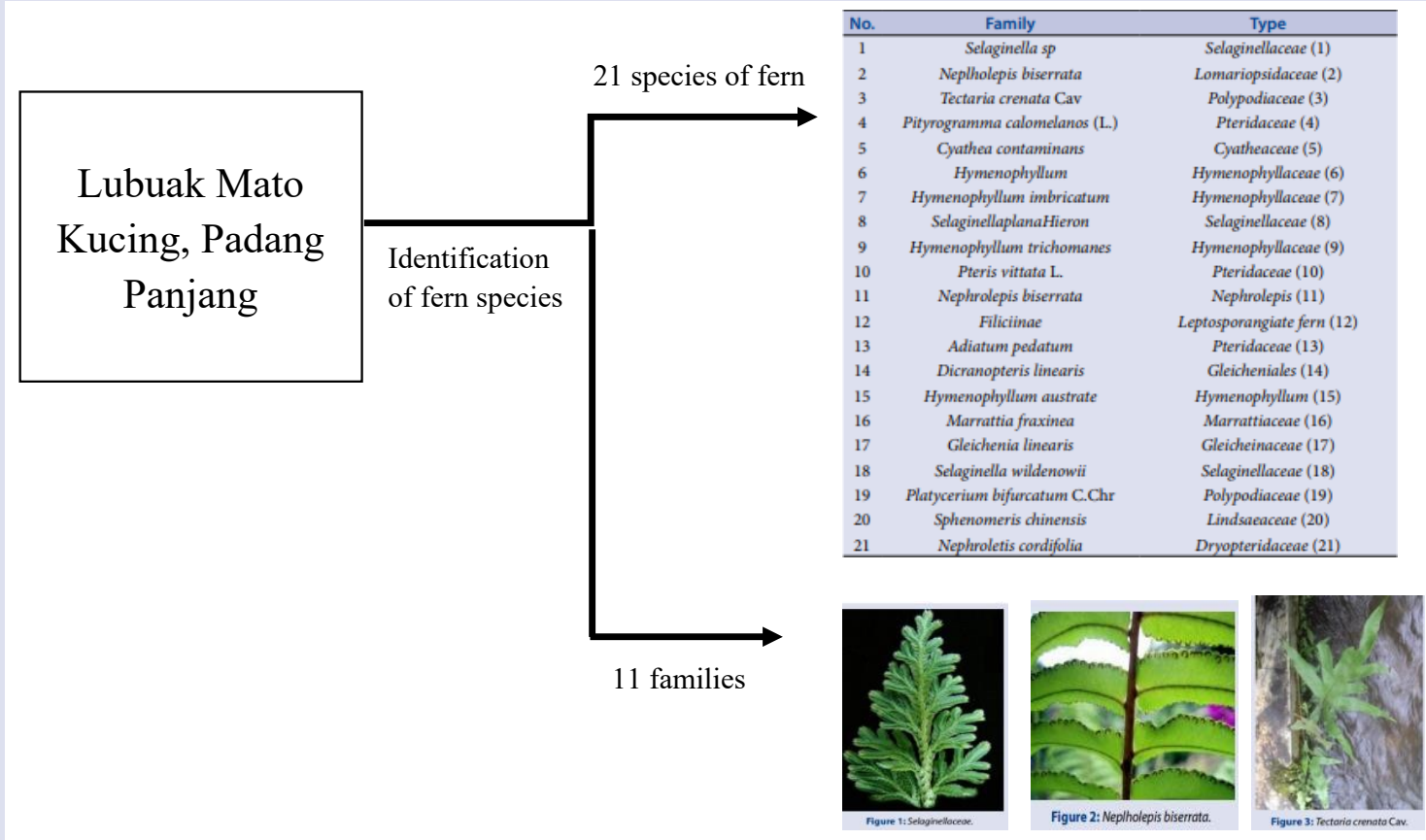

\section{SUMMARY}

The aim of this study obtains collect data and information about the diversity of ferns inLubuk Mato Kuciang. The activities of the study are conducted to collect species as much as possible. Identification of fern species was carried out in the Laboratory of Educational Science. Mathematics and Science Faculty. Padang State University. The identification of flora was analyzed descriptively. The identification species results were obtained through descriptive analysis. The results of this study obtained that there were 21 species of fern that include 11 families. They were namely; Selaginellaceace including Selaginella sp, Selaginella plana Hieron and Selaginella wildenowii; Lomariopsidaceae family including Neplholepis biserrata; Pterisvittata L; Adiatumpedatum; Cyatheaceae family, including Cyatheacontaminans; Gleicheinaceae including Gleichenialinearis; Marrattiaceae family including Marrattiafraxinea; Lindsaeaceae family including Sphenomeris chinensis; and Dryopteridaceae family including Nephrolepis cordifolia.

\section{ABOUT AUTHORS}

- Dr. Skunda Diliarosta, M.Pd; Currently as lecturer at Mathematics and Science Faculty, Universitas Negeri Padang. Doctoral program graduated from Universitas Negeri Padang. The research and expertise are in enviromental and science education. One of the new reasearch is about the effect of aglicultural extention for improvement enviromental behavior by vegetable farmer.

- Rehani Ramadhani; students of Natural Science Education Universitas Negeri Padang 2017, Graduated from ES 24 Ujung Gurun, JHS 13 Padang and SHS Ekasakti Padang. The research have been followed about Integration of Food safety and health consciousness in Padang and actives to be part of girlscout UNP.

- Dewi Indriani; students of Natural Science Education Universitas Negeri Padang 2017, Graduated from ES 08 Singgalang, JHS 5 Padang Panjang and SHS PGRII 3 Padang and actives to be part of Natural science student association.

Cite this article: Diliarosta S, Ramadhani R, Indriani D. Diversity of Pteridophyta in Lubuak Mato Kuciang Padang Panjang, Sumatera Barat. Pharmacog J. 2020;12(1):180-5. 